Nippon Suisan Gakkaishi $\quad$ 63(1), 97-102 (1997)

\title{
人工海水中にお打る低濃度オキシダントの 魚類病原微生物に対する殺菌・不活化効果
}

\author{
伊藤慎悟, 吉水守, 絵面良男 \\ (1996年 4 月 30 日受付)
}

\begin{abstract}
Disinfectant Effects of Low Level of Total Residual Oxidants in Artificial Seawater on Fish Pathogenic Microorganisms
\end{abstract}

Shingo Itoh,* Mamoru Yoshimizu,* and Yoshio Ezura*

\begin{abstract}
The disinfectant effects of total residual oxidants (TROs) produced by ozonization of artificial seawater on fish pathogenic bacteria and viruses were investigated. A dose of $0.1 \mathrm{mg} \mathrm{TROs} / l$ was not stable in natural seawater, but was stable in artificial seawater with a bromine compound (sodium bromide). By the treatment with TROs of $0.1 \mathrm{mg} / \mathrm{l}$ for 30 to 120 seconds, more than $99.9 \%$ of viable cells of Vibrio anguillarum, Aeromonas salmonicida, A. caviae, A. hydrophila, and Escherichia coli were killed, and $99.9 \%$ of infectivity of hirame rhabdovirus (HIRRV), infectious hematopoietic necrosis virus (IHNV), infectious pancreatic necrosis virus (IPNV), and yellowtail ascites virus (YAV) were inactivated. HIRRV was more than $99.7 \%$ inactivated by a treatment with a dose of $3.5 \mathrm{~g} / \mathrm{m}^{3}$ of ozone gas bubbles for $1 \mathrm{~min}$.
\end{abstract}

キーワート：オソソ, TROs, 魚類病原微生物, 殺菌効果

本産増養殖技術の発展七共に魚類病原譤告物による被 害も增大傾向にあり，特にウイルス病に対する対策は防 除・防疫に頼るしかない。魚類病原微生物の防除・防疫 法の一つとして飼育用水の殺菌法があげられる。現在, 魚類飼育用水の殺菌法としては紫外線が広く用いられ， 淡水域では紫外線を用いた魚類病瘏細菌の殺菌効果1》 ミズ力ビ類の菌系伸長阻止, ${ }^{2)}$ ウイルスの不活化効果, ${ }^{3)}$

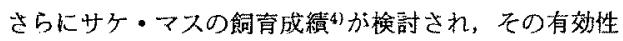
が報告されている。しかし, 紫外線殺菌法では水中の眯 濁粒子などより遮光される可能性や，低水温期に抢け る殺菌効果の低下，さらに現在市貶されている低圧ラン ブを用いた紫外線では殺菌されない病原媺生物む知られ ている。現在, 紫外線殺菌法と共に使用頻度が高い殺 菌法はオソン殺菌であり，淡水域ではオソンを用いた魚 類病原微生物の殺菌・不活化効果加認められている。5,6) 氷産業以外でもヨーロッパでは古くから上下水道の殺菌 などにオソンが使用されている。うかし，海水を対象 にしたオソン殺菌法の效果を報告した例は少なく， ${ }^{8,99}$ 海 水にオソ゚ンを注入することで生成される $\mathrm{BrO}_{3}^{-} や \mathrm{BrO}^{-}$ など（牫留オキシダント；Total Residual Oxidants，以 下TROs と略す）の魚類に対する毒性む報告10)されて
いる。骞際にオソソを使用している現場においても，使 用法によってはその殺菌効果に疑問を投げかける意 見11)もある。前報12)では TROs濃度を0.5 1.0 mg/l とした時に海水中に生成されたオキシダントの安定性と 魚類病原微生物に対する殺菌効果について検討し， TROs 濃度を $0.5 \mathrm{mg} / /$ 苛いは $1.0 \mathrm{mg} / l$ とし， 1 分間 処理することで供試した魚類病原細菌・ウイルス・㵶毛 虫を $99 \%$ 以上殺菌・不活化できることを報告した。12) 本報では，才ソン殺菌装㯰のランニングコストを下げる ため, TROs 濃度を前報12)上り低い $0.1 \mathrm{mg} / l$ 程度に設 定し，魚類病原細菌・ウィルスの殺菌・不活化効果を検 討した。

\section{材料と方法}

オソン発生装置 原料ガスとして酸素（函館酸菜 K.K.）を用い，地力調整機（日本フローセル），オソン 発生装膡（萑原実業 K.K.）索順次通過させオソンンを発 生させた。発生したオゾンを接触槽(ガス洗浄䞄； Vidrex）中の海水に注入することによりオキシダント を生成させた（Fig. 1)。

TROs 濃度の測定法 前報 ${ }^{12)}$ と同様にヨード法で

* 北海道大学水産学部微生物学諈座 (Laboratory of Microbiology, Faculty of Fisheries, Hokkaido University, Minato, Hakodate, Hokkaido 041, Japan). 


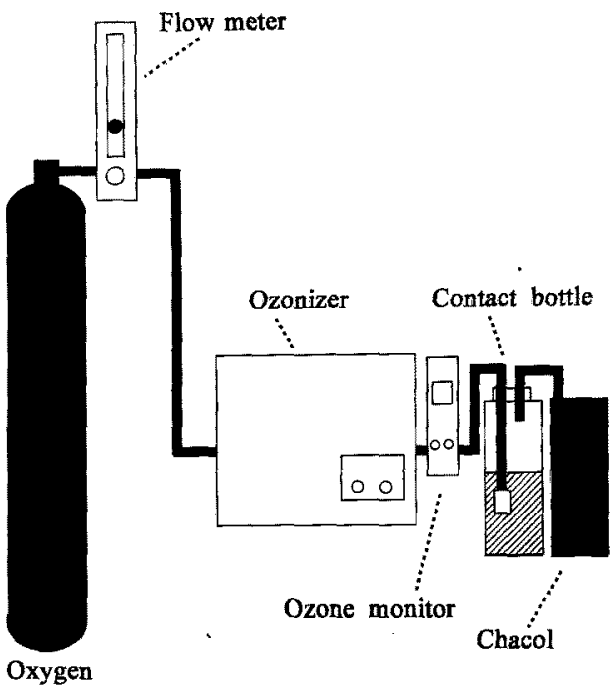

Fig. 1. Schematic illustration of seawater ozonization in this study.

TROs 湮度を測定した。海水試料を $1 \mathrm{~N}$ 硫酸で水菜イオ ン濃度を 6 K調節した後，1\%ヨウ化カリウムを $5 \mathrm{ml}$ 添加した。次に，1\%デンプン溶液を加え発色させた 啳， $0.001 \mathrm{~N}$ のチ才硫酸ナトリウム溶液で滴定した。な 怙，以下の式でTROs 浱度を測定した。

TROs 漶度 $(\mathrm{mg} / l)=a F \times 1,000 \times 0.024 \times 1 / X$

$a:$ 滴定量 $(\mathrm{m} l)$

$F: 0.001 \mathrm{~N}$ チ才硫酸ナトリウム溶液のファクター

$X:$ 海水試料 $(\mathrm{m} l)$

0.024:0.001 N チ才硫酸ナトリウム溶液 $1 \mathrm{~m} l$ 岕た りのオソン $0.024 \mathrm{mg} / \mathrm{l}$ に対応

供試海水 天然海水としては函館市立待押で採水した 海水妾供試し，人工海水としては Herbst（塩化ナトリ ウム $30.0 \mathrm{~g}$ ，壏化力リウム $0.7 \mathrm{~g}$ ，硫酸マグネシウム 7 水和物 $5.3 \mathrm{~g}$ ，塩化マグネシウム 6 水和物 $10.8 \mathrm{~g}$ ，犊酸 力ルシウム 2 水和物 $1.3 \mathrm{~g}$ ，蒸留水 $1 \mathrm{l}), 13$ ) Brujewicz (塩化ナトリウム $26.518 \mathrm{~g}$, 塩化カリウム $0.725 \mathrm{~g}$, 硫 酸マグネシウム $3.305 \mathrm{~g}$ ，塩化マグネシウム $2.447 \mathrm{~g}$ ， 塩化カルシウム $1.141 \mathrm{~g}$ ，宸酸水素ナトリウム $0.202 \mathrm{~g}$, 臭化ナトリウム $0.083 \mathrm{~g}$ ，蒸留水 $(l)^{14}$ 拈上びLyman \& Fleming（塩化ナトリウム23.476 g，揂化カリウム $0.664 \mathrm{~g}$ ，硫酸ナトリウム $3.917 \mathrm{~g}$ ，塩化マグネシウム $4.981 \mathrm{~g}$, 塩化カルシウム $1.102 \mathrm{~g}$, 炭酸水素ナトリウム $0.192 \mathrm{~g}$, 臭化力りウム $0.096 \mathrm{~g}$ ，ほう酸 $0.026 \mathrm{~g}$ ，塩化 ストロンチウム $0.024 \mathrm{~g}$, フッ化ナトリウム $0.003 \mathrm{~g}$, 蒸留水 $1 l)^{14)}$ の人工海水を供試した。また，前述の
Herbst の人工海水に $83 \mathrm{mg} / \mathrm{l}$ の臭化ナトリウム（莫素 漕度 $64 \mathrm{mg} / l$ ) を添加した人工海水む供試した。

各供試海水中の残留オキシダント（TROs）の安定性 各供試海水にオソンを注入後 0〜10分間のTROs 湿度 を前述の方法により測定した。

供試ウイルスおよび培垠細胞 供試ウイルスとして， サケ科魚類の伝染性造血器流死淀ウイルス (IHNV $\mathrm{ChAb}$ 株) と伝染性膵葴壊死症ウイルス (IPNV VR299 抹)，ヒラメラブドウイルス（HIRRV 8401-H株)， プリ (Seriola quinqueradiata) のウイルス性腹水症ウイ ルス (YAV) を供した。IHNVについては, 4,000×g で30 分間遠心分離することにより細胞片を取り除き， さらに $55,000 \times g$ で 120 分間遠心分離し，生成した沈 殷をりン酸楥重液（塩化ナトリウム $8.0 \mathrm{~g}$ ，塩化力リウ $\Delta 0.2 \mathrm{~g}$ ，リン酸水素二ナトリウム $1.15 \mathrm{~g}$ ，リン酸二水 素力リウム $0.2 \mathrm{~g}$ ，蒸留水 $1 l . \mathrm{pH} 7.3$, 以下PBS 上称 す）に慜濁し、これをウイルス液とした。IPNV，

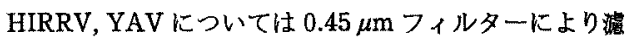
過した液をウイルス液とした。なお，IHNV，YAVの培 責にはマスノスケ (Oncorhynchus tschawytscha) の肧由 来である CHSE-214 (chinook salmon embryo) 緗胞を, HIRRVの培差にはコイ（Cyprinus carpio）の上皮睡由 来である EPC (epithelioma papilosum cyprini) 細脆を 用いた。細胞の培着は $10 \%$ 牛胎児血清 (Gibco), ペニ シリン (Sigma) $100 \mathrm{I} . \mathrm{U} . / \mathrm{ml}$ 、 ストレプトマイシン (Sigma) $100 \mu \mathrm{g} / \mathrm{ml}$ ，トリス㣪街液 [0.17\% Tris-(hydroxymethyl)-aminomethane- $\mathrm{HCl}$ および $0.063 \%$ Tris(hydroxymethyl)-aminomethane, $\mathrm{pH}$ 7.8: Sigma] およ び $0.75 \%$ 炭酸水素ナトリウム（和光純薬）を含む Eagles'minimum essential medium (Gibco) を使用し た。

供試細菌供陚細菌として Vibrio anguillarum (NCMB 6 株), Aeromonas salmonicida (ATCC 14174 株), A. hydrophila (IAM 1018株), A. caviae (TUF 1 株)，Escherichia coli (0-26 珠) を供した。V. anguillarum の培責には液体海水培地（ポリベプトン $5 \mathrm{~g}$, 酵母

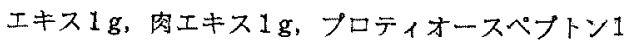
$\mathrm{g}, 75 \%$ Herbst 人工海水 $1 l, \mathrm{pH} 7.8)$ を，A. salmonict da, A. caviae, A. hydrophila, E. coli の培養には普通フイ ヨン(ポリペプトン $10 \mathrm{~g}$, 肉エキス $5 \mathrm{~g}$, 塩化ナトリウ $\triangle 1.2 \mathrm{~g}$ ，蒸留水 $1 l, \mathrm{pH} 7.2)$ を用い， $20^{\circ} \mathrm{C}$ て 1 週間培 㙋後， $1,500 \times g, 30$ 分間遠心分離した。沈段をPBSK 慗濁し，再び $1,500 \times g$ で 30 分闇遠心分離することで 菌体を洗海した。菌体を再じPBSに䀣濁し， Mcfarland No.3 に濃度を調整した菌体を菌液として実 験に供試した。なお，供試紐菌の生菌数は，V，anguillarum では海水寒天培地（先の液体培地に寒天を $15 \mathrm{~g}$ 加 
えたもの）を用い，他の供試菌株には普通寒天培地を用 いて測定した。

魚類病原微生物の殺菌・不活化効果 各供試种菌秝渴 液を $0.1 \mathrm{mg} / /$ の TROs 含有の Brujewicz の人工海水に $1 \%$ 割合で混合し， $20^{\circ} \mathrm{C}$ で一定時間経過後にそれぞ れ $1 \mathrm{ml}$ 採取し，等量の液体海水培地むしくは普通ブイ ヨンを加えてTROs の反応を停止してこの反㧤停止液 の生菌数を求めた。ウイルス液についてむ同浱度の TROs を含む Brujewicz の人工海水に $0.01 \%$ の割合で 混合L, 一定時間経過後, $1 \mathrm{~m} l$ を採取し, 等量の牛胎 見血清により反応を停止させ，このウイルス液の感染価 を湘定してウイルスに対する不活化効果を求め大。対照 としては無処理の人工海水に供試微生物を加え，反沁宗 止㳸を添加した液から生菌数もしくはウイルス感染価を 求めオキシダント処理した時の值と比較した。

オソンガス気泡による HIRRV 不活化効果 HIRRV 液を $0.01 \%$ の割合で蒸留水に添加し，オソ゚ン濃度を $3.5 \mathrm{~g} / \mathrm{m}^{3}$, 圧力を $0.5 \mathrm{~kg} / \mathrm{l}$, 流量を $1 \mathrm{l} / \mathrm{min} と し て, ~ 1$ 分問処理した後のウイルス感染価を測定すると共に，同 一条件で天然海水をオソン処理した場合に生成される TROsの淔度を測定し，このTROs 濃度での HIRRV 不活化效果を測定した。なた，対照として，オソンンの代 わりにオソン生成に使用している酸菜ガスを蒸留水に同 一条件で吹き込み，ウイルス感染価を測定した。

\section{結果}

天然海水および人工海水中における TROs の安定性 天然海水中にオソンソを吹き込み，TROs 濃度を 0.12 お よび $0.13 \mathrm{mg} / \mathrm{l}$ とした場合のTROs濃度の経時変化を Table 1 に示した。5 分後にはいずれの惯度でもヨウ化 カリウムが発色せす，TROs 濃度を測定できなくなっ た。

次に，各人工海水中でのTROs の安定性を挨討した (Table 1)。Herbst の人工海水中に打ける TROs 濃度 は，スタート時を 0.22 扰よび $0.17 \mathrm{mg} / \mathrm{l}$ とした場合， 5 分後にはそれぞれ $0.20 \mathrm{mg} / l$ および $0.13 \mathrm{mg} / \mathrm{l}$ とな り，10 分後には 0.18 および $0.11 \mathrm{mg} / \mathrm{l}$ と徐々に濃度が 低下していった。一方，Lyman \& Fleming の人工海水 中での TROs 濃度はスタート時に $0.10,0.13 \mathrm{mg} / \mathrm{l}$ であ ったものが，5分および 10 分後ですほほ同程度の值を 示した。さらにBrujewiczの人工海水中に扣ける TROs 濃度もスタートを 0.14 扰よび $0.13 \mathrm{mg} / \mathrm{l}$ とした 場合，10 分後でむ同し値となり，臭化物を含まない Herbst の人工海水に比へ，臭化物を含むLyman \& Fleming 拉よび Brujewicz の人工海水では，TROs 濃度 は減少せす安定であった。そこで，臭化ナトリウムを

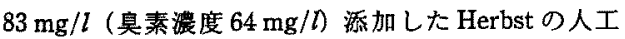

Table 1. Stability of TROs produced by ozonization in seawater

\begin{tabular}{lrll}
\hline \multicolumn{1}{c}{ Seawater } & $\begin{array}{c}\text { Time } \\
\text { (minute) }\end{array}$ & \multicolumn{2}{c}{$\begin{array}{c}\text { TROs } \\
\text { concentration } \\
(\mathrm{mg} / \mathrm{l})\end{array}$} \\
\hline & 0 & 0.12 & 0.13 \\
Natural seawater & 5 & ND* & ND \\
& 10 & $\mathrm{ND}$ & $\mathrm{ND}$ \\
\hline & 0 & 0.22 & 0.17 \\
Herbst's ASW** & 5 & 0.20 & 0.13 \\
& 10 & 0.17 & 0.12 \\
\hline & 0 & 0.10 & 0.13 \\
Lyman \& Fleming's ASW & 5 & 0.10 & 0.14 \\
& 10 & 0.09 & 0.11 \\
\hline \multirow{3}{*}{ Brujewicz's ASW } & 0 & 0.14 & 0.13 \\
& 10 & 0.14 & 0.13 \\
\hline \multirow{2}{*}{ Herbst's (with 83 mg/lof } & 0 & 0.15 & 0.25 \\
NaBr) ASW & 5 & 0.15 & 0.25 \\
& 10 & 0.15 & 0.25
\end{tabular}

* : ND; Not detected.

**: ASW; Artificial seawater.

Table 2. Effects of TROs on reduction rate of viable counts of fish pathogenic bacteria in Brujewicz's artificial sea water

\begin{tabular}{lccr}
\hline \hline Bacteria & $\begin{array}{c}\text { Treatment } \\
\text { time } \\
\text { (second) }\end{array}$ & $\begin{array}{c}\text { TROs } \\
\text { concentration } \\
(\mathrm{mg} / \mathrm{l})\end{array}$ & $\begin{array}{c}\text { Reduction } \\
\text { rate } \\
(\%)\end{array}$ \\
\hline V. anguillarum & 30 & 0.12 & 99.4 \\
& 60 & 0.12 & $>99.9$ \\
A. salmonicida & 30 & 0.11 & $>99.9$ \\
A. caviae & 30 & 0.10 & 99.9 \\
A. hydrophila & 30 & 0.11 & 99.5 \\
& 60 & 0.11 & $>99.9$ \\
E. coli & 60 & 0.10 & 97.5 \\
& 120 & 0.10 & 99.9 \\
\hline
\end{tabular}

海水を作成し，オキシダントの安定性を検討した。スタ 一ト時のTROs 濃度 0.15 括よび $0.25 \mathrm{mg} / \mathrm{l}$ は， 5,10 分経過後む 0.15 および $0.25 \mathrm{mg} / \mathrm{l}$ となり，TROs 湄度 に変化は認められなかった。

TROsの魚類病原細菌に対する殺菌効果 Brujewicz の人工海水中の TROs 濃度を $0.10 \sim 0.12 \mathrm{mg} / l$ とし，

$V$, anguillanum, $A$. salmonicida, A. hydrophila, A. caviae, E. coli 30〜120秒間处理した場合の生菌数の隇少率 を Table 2 に示した。生菌数を $99 \%$ 以上減少させるた めに必要な始理時間讷 $V$. anguillarum, $A$. salmonicida, A. caviae, A. hydrophila で 30秒, E. coli の場合は, 120 
秒であった。

TROsの魚類病原ウイルスに対する不活化効果 Brujewiczの人工海水を用い，TROs滥度を 0.11 ある いは $0.14 \mathrm{mg} / l$ とし，供試ウイルスと反応さ世た場合の 結果を Table 3 に示した。HIRRV とIHNVの場合, 0.11 お 上し $0.14 \mathrm{mg} / \mathrm{l}$ の TROsを含む人工海水上 30 秒 間反応させ大場合，反の感染洒は $99.9 \%$ 以上減少した。 IPNVの場合は 30 秒の処理で 68.4\%不活化され，60 秒後に検出限界以下になった。なた，YAVの場合む 120 秒後に $99.9 \%$ 以上不活化された。

オソンガス気泡による HIRRV 不活化効果 オソン ガス気泡の HIRRV に及ぼす影镜を Table 4 に示した。 蒸留水にオソンガスを吹き込んで処理したときの HIRRV 感染洒は酸素ガスをコントロールとして処理し たHIRRVに比へ，99.7\%以上减少した。この時の TROs 測定限界以下であった。一方, 天然海水を同じ 条件で 60 秒間処理したときの TROs 濃度は $0.46 \mathrm{mg} / \mathrm{l}$ であった。また, TROs 濃度が $0.52 \mathrm{mg} / l$ で 1 分間処理 したときのHIRRV 不活化率は 99.9\%と測定をれた。

Table 3. Inactivation of fish pathogenic viruses by TROs in Brujewicz's artificial sea water

\begin{tabular}{lcrrr}
\hline \hline Virus & $\begin{array}{c}\text { Treatment } \\
\text { time } \\
\text { (second) }\end{array}$ & $\begin{array}{c}\text { TROs } \\
\text { concent- } \\
\text { ration } \\
\text { (mg/l) }\end{array}$ & $\begin{array}{c}\text { Recuction } \\
\text { rate (\%) }\end{array}$ & $\begin{array}{c}\text { Initial } \\
\text { virus titer }\end{array}$ \\
\hline HIRRV & 30 & 0.11 & $>99.9$ & $3.80^{*}$ \\
IHNV & 30 & 0.14 & $>99.9$ & 4.05 \\
IPNV & 30 & 0.11 & 68.4 & 3.30 \\
& 60 & 0.11 & $>99.7$ & 3.30 \\
YAV & 60 & 0.11 & 99.4 & 3.80 \\
& 120 & 0.11 & $>99.9$ & 3.80 \\
\hline
\end{tabular}

* $: \log \mathrm{TCID}_{50} / \mathrm{ml}$
考察

本実験では最初に海水中に生成したオキシダントの安 定性を知るため, 海水中での TROs 濃度を経時的に測

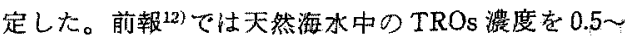
$1.0 \mathrm{mg} / l$ とした場合, TROs 濃度測定開始か 580 分間

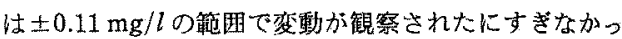
た。しかし， $0.1 \mathrm{mg} / l$ 程度の低 TROs 濃度の綎時的変 化古测定したところ，测定閏始より5分経過した時点 ですでにヨード法では測定不能となった（Table 1)。こ のこ上から，実際に天然海水へオソンをを注入し，低濃度 オキシダントで海水を殺菌する場合には，TROs 濃度を モニターし, 常に $0.1 \mathrm{mg} / l$ となるようにオソン発生器 の出力を調整する必要があることが示唆された。

天然海水の場合, $0.1 \mathrm{mg} / \mathrm{l}$ 程度の TROs 濃度では海 水中の有機物等て TROs 怔消費されたと考えられる。 そこで，有機物等が含末れていない人工海水を用い， TROs 濃度が $0.1 \mathrm{mg} / l$ 程度に打けるTROs の安定性を 検討した。具菜化合物含含ないHerbst の人工海水て は，測定開始時からTROs濃度が徐々に低下した。し 加し，卓素化合物を含む Lyman \& Fleming の人工海水 扣よびBrujewiczの人工海水の場合，スタート眭の TROS 濃度が 10 分後心も変化なく，臭化物を含まない Herbst の人工海水に比へ，臬化物を含む人工海水の方 が安定であることが明らかたなった（Table 1)。

そこで，人工海水中の臭素化合物が TROs 濃度の安 定性に関与しているかについて知るために $83 \mathrm{mg} / \mathrm{l} の$ 臭化ナトリウムを添加した Herbst の人工海水を作製 し，この人工海水中での TROs の安定性を検討した。 スタート時の TROs 濃度が 0.15 および $0.25 \mathrm{mg} / /$ の場 合，300抢よひ 600 秒後でも同じ值を示した。この結 果は臭素化合物を含むBrujewicz の人工海水やLyman \& Fleming $の$ 人工海水上同様，臭素化合物の添加によ りTROsの安定性が増加することを示す結果となった。

Table 4. Effect of ozone gas bubbles on HIRRV infectivity

\begin{tabular}{|c|c|c|c|c|}
\hline \multirow{2}{*}{$\begin{array}{l}\text { Treatment } \\
\text { condition }\end{array}$} & \multirow{2}{*}{$\begin{array}{l}\text { TROs } \\
\text { concentration } \\
(\mathrm{mg} / l)\end{array}$} & \multicolumn{2}{|c|}{ Infectivity of HIRRV } & \multirow{2}{*}{$\begin{array}{l}\text { Reduction } \\
\text { rate } \\
(\%)\end{array}$} \\
\hline & & $\begin{array}{c}\text { Initial } \\
\mathrm{TCID}_{50} / \mathrm{m} l\end{array}$ & $\begin{array}{l}\text { After ozone } \\
\text { gas treatment }\end{array}$ & \\
\hline $\begin{array}{l}\text { Distilled } \\
\text { water* }\end{array}$ & Trace & 3.30 & $\leqq 0.80$ & 99.7 \\
\hline $\begin{array}{l}\text { Natural } \\
\text { seawater }\end{array}$ & 0.46 & $\mathrm{NT}^{* *}$ & NT & NT \\
\hline $\begin{array}{l}0.5 \mathrm{mg} / l \mathrm{TRO} \\
\text { in natural } \\
\text { seawater }\end{array}$ & 0.52 & 5.80 & 2.80 & 99.9 \\
\hline
\end{tabular}

* : Air pressure $0.5 \mathrm{~kg} / \mathrm{cm}^{2}$, Air supply $1 \mathrm{l} / \mathrm{min}$, ozone gas concentration $3.5 \mathrm{~g} / \mathrm{cm}^{3}$, Supplied time $1 \mathrm{~min}$ **: Not tested 
使用する試薬数などを考慮するとBrujewiczの人工海 水加適当と考えられ，以後この人工海水を用い実験を行 っ。

前報12)では，天然海水にオゾンを注入し，TROs 濃度 が 0.5 あるいは $1.0 \mathrm{mg} / \mathrm{l}$ の TROs を含有する海水に魚 類病原紐菌およびウイルスを混合して所定時間反応させ た後に生菌数あるいは感染価を測定した。生成した TROs 謴度が 1.0 および $0.5 \mathrm{mg} / \mathrm{l}$ の場合，V. anguillarum 抢よびHIRRVは共に15秒の処理により99 $99.9 \%$ 以上殺菌あるいは不活化され，A. salmonicida, A. caviae, A. hydrophila, E. coli † IHNV \& 15 秒の処理 で不活化・殺菌された。また，IPNVでは 99\%以上の 感染価を減少させるためには 30 秒，YAVでは 60 秒の 処理が必要であった。ところで TROs 濃度を 0.5 おる いは $1.0 \mathrm{mg} / l$ とするには装置が大型化し，ランニング コストむ大きくなるため，上り低濃度での殺菌効果が羿 められれば，経費はかなり節減される。

そこで，今回は低濃度での TROs の殺菌・不活化効 果の検討を行う目的で上記の臭素化合物を゙含む人工海水 を用い，0.1 mg/lでの TROs の殺菌・ウイルス不活化 效果を検討した。Brujewiczの人工海水を用いTROs 濃 度を $0.1 \mathrm{mg} / l$ 程度とし，魚類病原細菌の殺菌およびウ イルスの不活化効果を同様に検討した。魚類病原細菌お よびウイルスの生菌数あるいは感染洒を $99.9 \%$ 以上も しくは検出限界以下まで减少させるには，A. salmonicida, A. caviae, HIRRV おちよび IHNV の場合は 30 秒処理 する必要があり，A. hydrophila および IPNV の場合は 60 秒, YAV, V. anguillarum, E. coli の場合は 120 秒处 理する必要があった。以上の結果より，TROs 濃度が $0.1 \mathrm{mg} / \mathrm{l}$ 以上で 120 秒間処理することにより供試した 全ての微生物を $99.9 \%$ 以上もしくは检出限界以下なで 殺菌・不活化できると判断された（Table 2,3)。

ところで, 海水にオソンを吹き込み，海水をオソン処 理すると多数の微䋖オソンガス気泡が生じる。このオソ ンガス気泡の微生物に対する影響を HIRRVを対象に検 討した。オキシダントが生成されないという条件を得る ために蒸留水を用い，オソンガス気泡による HIRRV 不 化效果を測定し，次いで同一条件下で天然海水を処理 し，生成するTROsによる不活化效果を比敨検討した。 オソンカスス気泡による不活化率は $99.7 \%$ 以上となった。 また，オソンンカスス気泡を蒸留本と接触させた場合と同条 件で天然海水と接触させた後に生成するTROs濃度は $0.46 \mathrm{mg} / l$ であり，この謷度とほぼ同じ濃度で 60 秒間 反応させた場合の HIRRV 不活化率は $99.9 \%$ であった (Table 4)。この結果から，オソンンガス気泡にむかなり のウイルス不活化能力があると考えられる。

一方, Wedemeyer et al. ${ }^{5,6)}$ は, 炭酸力ルシウム不含
の PBDW (phosphate-buffered distilled water) 中で残 留オソン濃度を $0.01 \sim 0.04 \mathrm{mg} / l$ にし，30〜60 秒間処 理することにより IHNV，IPNV，A. salmonicidaを 99.99 99.999\%以上殺菌・不活化することがでさると 報告している。この值は今回のTROsによる殺菌・不 活化効果以上に效果があ石と考えられる。しかし，春際 に硬水や軟水の湖水を用い, 残留オゾン濃度が 0.01 $\mathrm{mg} / l$ となるようにオソンガスを吹き込んだ場合， IHNV や IPNV を $99 \%$ 以上不活化させるには 2 分間以 上が必要であり，6) PBDW にオソンを溶解させた場合や オキシダントに比べ不活化効果が低いと考えられる。

また, Sugita et al. $\left.{ }^{9}\right)$ は純培算した細菌をオキシダント 処理したときの殺菌率と，種々の細菌が多数存在してい る沿岸海水をオキシダント処理した場合を比べると，沿 岸海水に対する殺菌率が低下することを示している。こ のことから，実際にオゾンを用い，殺菌を目的として天 然海水を処理する場合は実験室レベルで設定したオキシ ダント濃度よりも高めの濃度で処理する必要性があると 推測される。いずれにしてむ海水をオソン処理により殺 菌する場合には，オソンの海水への注入に上り生成され るオキシダント濃度を常にモ二ターし，オキシダント濃 度が $0.1 \mathrm{mg} / l$ となるようにオソン発生器の出力を調整 する必要があると考えられる。

\section{文献}

1）木村雷久，吉水 守，田島研一，絵面良男，坂井 稳 : 逢 魚用水の函外線殺菌法に一いて一I，魚類病原細菌ならび に筑魚用水生存菌の柴外線感受性. 日水誌，42，207-211 (1976).

2）木村喬久，吉水守，田島研一，絵面良男：善魚用水の

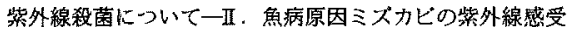
性について. 魚病研究. 14, 133-137 (1980).

3）吉水 守，激沢芸子，木村喬久：魚類病原ウイルスの紫 外線感受性. 魚病研究. 21，47-52 (1986).

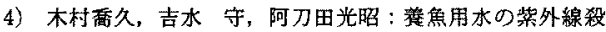
菌について一III.U.V. 処理本使用によるサケ・マス艀化 成續について。魚病䂙究. 14, 139-142 (1980).

5) G. A. Wedemeyer and N. C. Nelson: Survival of two bacterial fish pathogens (Aeromonas salmonicida and enteric red mouth bacterium) in ozonated, chlorinated, and untreated waters. J. Fish, Res. Bd. Canada, 34, 429-432 (1977).

6) G. A. Wedemeyer, N. C. Nelson, and C. A. Smith: Survival of the salmonid viruses infectious hematopoietic necrosis virus (IHNV) and infectious pancreatic necrosis virus (IPNV) in ozonated, chlorinated, and untreated waters. $J$. Fish. Res. Bd. Canada, 35, 875-879 (1978).

7) 内藤茂三：オソン殺菌装塧.「改生物制御実用事典」(石

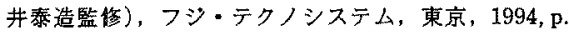
417 .

8）吉水守，日向進一；羔魚用水の殺菌法一紫外線及びオ ソンの利用一，工業用水，404，2-8 (1992).

9) H. Sugita, T. Asai, K. Hayashi, T. Mituya, K. Amanuma C. Maruyama, and Y. Deguchi: Application of ozone disinfection to remove Enterococcus seriolicida, Pasteurella pisci- 
cida, and Vibrio anguillarum from sea water. Appl. Environ. Microbiol., 58, 4072-4075 (1992).

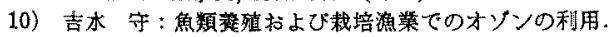
オソン年璼 93-94 年度版，リアライズ社，東京，1992。 pp. $401-409$.

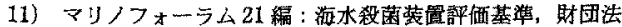
人マリノフォーラム21, 東京, 1991 , pp. 54-63, 80-89.

12) M. Yoshimizu, S. Hyuuga, M.J. Oh, Y. Ezura, S. Ito, and G. Mimura: Disinfectant effect of oxidant produced by ozonization of sea water on fish pathogenic viruses, bacter- ia, and ciliata. In Diseases in Asian Aquaculture II. M. Schariff, J. R. Arthur \& R. P. Subasinghe (eds.), Fish Health Section, Asian Fisheries Society, Manita, 1995, pp. 203-209.

13）中村 浩：海洋数生物. 微生物学ハンドブック，技報往， 東京, 1962, pp. 610-621.

14) H. U. Sverdrup, M. W. Johnson, and R. H. Fleming: The oceans their phisics, chemistry, and general biology. Prentice-Hallinc., Engle wood Cliffrs. N. J. Charles E. Tuttle Company, Tokyo, 1966, pp. 185-186. 